DOI: $10.1590 / 1089-6891 v 16 i 217226$

PRODUÇÃO ANIMAL

\title{
CHEMICAL AND ENERGETIC CONTENT OF CORN BEFORE AND AFTER PRE-CLEANING
}

\section{CONTEÚDO QUÍMICO E ENERGÉTICO DO MILHO ANTES E APÓS PRÉ- LIMPEZA}

\author{
Sandra lara Furtado Costa Rodrigues ${ }^{1}$ \\ José Henrique Stringhini ${ }^{2}$ \\ Márcio Ceccantini ${ }^{3}$ \\ Antonio Mário Penz Júnior ${ }^{4}$ \\ Andrea Machado Leal Ribeiro 4 \\ Vanessa Peripolli ${ }^{5}$ \\ Concepta Margaret McManus ${ }^{6}$ \\ 'Zootecnista, Doutora, Novus do Brasil, Indaiatuba, SP, Brasil. \\ 2Professor Doutor, Universidade Federal de Goiás, Goiânia, GO, Brasil, Bolsista CNPq. \\ ${ }^{3}$ Adisseo do Brasil, Paulínia, SP, Brasil \\ ${ }^{4}$ Professores Doutores da Universidade Federal do Rio Grande do Sul, Porto Alegre, RS, Brasil. \\ ${ }^{5}$ Pós-Doutoranda da Universidade de Brasília, Brasília, DF, Brasil. \\ ${ }_{6}^{6}$ Professora Doutora da Universidade de Brasília, Brasília, DF, Brasil, Bolsista CNPq - concepta@unb.br
}

\begin{abstract}
The poultry industry normally has little control over the raw material that arrives at the processing plant. This experiment aimed to evaluate chemical and energetic quality of corn obtained in a feed mill before and after pre-cleaning. Twenty samples of $30 \mathrm{~kg}$ of corn each were taken from trucks delivering corn to the mill. The trucks were then unloaded and the material passed through a pre-cleaning process when another sample was taken. Samples were graded and physical properties evaluated: density (g/L), grain percentages of foreign material, impurities, fragments, broken, soft, insect damaged, fire-burnt, fermented, damaged, cracked and fine particles, as well as chemical composition analysis: Apparent metabolizable energy for poultry (AME), ether extract (EE), crude fiber (CF), starch (STA), water activity (WA), crude protein (CP), digestible and total lysine, methionine, cystine, threonine, tryptophan, valine, isoleucine, leucine, phenylalanine, histidine and arginine. The experiment was a randomized design with two treatments (before and after pre-cleaning) and twenty replications. Data was analyzed using SAS ${ }^{\circledR}$ and treatment differences obtained using F test. Correlations and principal components were calculated. There was a decrease in density after the pre-cleaning process, which was probably due to the removal of earth and stones rather than grain and its fractions. Significant increases were found for insect damage, fermented and damaged grain while fire-burn was significantly reduced after the pre-cleaning process. Starch increased after pre-cleaning which is a result of contaminants that normally are poor in this carbohydrate, but fiber levels increased too. Apparent metabolizable energy, aminoacids, digestible $(\mathrm{P}<0.05)$ and total $(\mathrm{P}<0.05)$ histidine, total lysine and methionine $(\mathrm{P}<0.1)$ levels were reduced after pre-cleaning. Density was higher when there were fewer impurities
\end{abstract}


such as straw, husk or small grains. Broken corn was positively correlated $(\mathrm{P}<0.05)$ with foreign material (0.63) and fragments (0.76), while proportion of damaged corn was positively correlated with foreign material (0.68), fragments (0.58) and broken corn (0.83). In this study, even in samples classified as excellent quality before pre-cleaning, the pre-cleaning process was effective in reducing humidity and water activity which helps control the growth of fungi or other microorganisms. Starch and fiber levels increased after pre-cleaning while apparent metabolizable energy levels was not improved by pre-cleaning.

Keywords: density; energy; humidity; protein; starch.

\section{Resumo}

A indústria avícola normalmente tem pouco controle sobre a matéria-prima que chega à unidade de transformação. Este experimento teve como objetivo avaliar a qualidade química e energética do milho obtida em uma fábrica de rações, antes e após a pré-limpeza. Vinte amostras de $30 \mathrm{~kg}$ de milho, foram retiradas de caminhões que entregavam milho para o moinho. Após os caminhões serem descarregados e o material passar por processo de pré-limpeza, outra amostra foi retirada. As amostras foram classificadas e as propriedades físicas foram avaliadas: densidade (g/L), percentagens de grãos de material estranho, impurezas, fragmentados, quebrados, chocho, danificados por insetos, queimados, fermentados, danificados,avariados e quirera, bem como análises de composição bromatológica: energia metabolizável aparente para aves (EMA), extrato etéreo (EE), fibra bruta ( $\mathrm{FB})$, amido $(\mathrm{A})$, atividade de água $(\mathrm{AA})$, proteína bruta $(\mathrm{PB})$, lisina digestível e total, metionina, cistina, treonina, triptofano, valina, isoleucina, leucina, fenilalanina, histidina e arginina. O delineamento experimental foi o inteiramente casualizado com dois tratamentos (antes e após a pré-limpeza) e vinte repetições cada. Os dados foram analisados usando o programa SAS ${ }^{\circledR}$ e as diferenças entre os tratamentos obtidos pelo teste F. Correlações e componentes principais foram calculados. Houve diminuição na densidade após o processo de prélimpeza que foi provavelmente devido à remoção de terra e pedras em vez de grão e as suas fracções. Aumentos significativos foram encontrados para danos causados por insetos, grãos fermentados e danificados, enquanto o nível de queimados foi significativamente reduzido após o processo de pré-limpeza. O amido aumentou após a pré-limpeza já que contaminantes normalmente são pobres neste componente, porém os níveis de fibra também aumentaram. Os níveis de energia metabolizável aparente, aminoácidos, digestibilidade aparente $(\mathrm{P}<0,05)$ e total $(\mathrm{P}<0,05)$ da histidina, de lisina total e metionina $(\mathrm{P}<0,05)$ foram reduzidos após a pré-limpeza. A densidade foi maior quando havia menos impurezas, como a casca de palha ou grãos pequenos. A presença de milho quebrado foi positivamente correlacionada $(\mathrm{P}<0,05)$ com material estranho $(0,63)$ e fragmentos $(0,76)$, enquanto que a proporção do milho danificado foi positivamente correlacionado com material estranho $(0,68)$, os fragmentos $(0,58)$ e milho quebrado $(0,83)$. Neste estudo, mesmo as amostras sendo classificadas como de excelente qualidade antes da pré-limpeza, o processo de pré-limpeza foi eficaz em reduzir a umidade e atividade da água, que ajuda a controlar o crescimento de fungos ou outros microorganismos nas rações. Os níveis de amido e fibra aumentaram após a pré-limpeza, enquanto que os níveis de energia metabolizável aparente não foram melhorados pela pré-limpeza.

Palavras-chave: amido; densidade; energia; proteína; umidade.

Recebido em: 15 fevereiro 2012

Aceito em: 10 outubro 2014

Cienc. anim. bras. v.16, n.2, p. 158-168 abr./jun. 2015 


\section{Introduction}

The quality of ingredients used for feed production by a poultry feed milling facility is important because what the birds eat can affect flock and product quality, as well as directly affect the profit of the poultry business ${ }^{(1)}$. The poultry industry normally has little control over the raw material that arrives at the processing plant, as raw feed ingredients are grown, harvested, stored, and transported by someone outside of the poultry industry. Therefore, the ingredient quality control component of a poultry feed mill operation is an important first step in assuring a healthy diet for the birds.

Alterations in the quality of feedstuffs in Brazil are some of the most important problems that the animal food industry faces and can affect feed quality and therefore animal performance ${ }^{(2)}$. Corn is the crop which occupies the largest cultivated area in Brazil and is used in both human and animal nutrition. The evaluation of physical quality of grain is an important tool to guarantee corn quality for ration use. Data collected to determine the influence of chemical and physical properties of corn on animal performance ${ }^{(3)}$ as well as how pre-cleaning affects physical quality of corn are limited in literature.

Corn is assigned an official grade ${ }^{(4)}$ based on quality descriptors including minimum test weight, maximum limits of damaged kernels, as well as broken corn and foreign material. Mechanical damage in grain can occur during harvesting, drying, transport and cleaning, which may give rise to cracked and damaged grains. A series of questions should be taken in to account in the feed mill including excess humidity, presence of cracked and damaged grains, weed seeds, fire-burnt, foreign material, mould and aflatoxins ${ }^{(2,5)}$. These authors reiterate that if the corn is analyzed when it is received in the mill, $90 \%$ of the problems can be detected and they highlight the importance of the pre-cleaning analysis. Knowledge of energy content of percent broken corn and foreign material would be useful to properly characterize energy content and hence feeding value of incoming corn samples. This experiment aimed to evaluate chemical and energetic quality of corn obtained in a feed mill before and after pre-cleaning.

\section{Material and Methods}

This study was carried out in the Asa Alimentos Feed Mill in Brasilia, DF, Brazil. Twenty samples of $30 \mathrm{~kg}\left(0.0002 \%\right.$ of the total load, according to Brazilian Federal Regulations - Brazil $\left.{ }^{(4,6)}\right)$ of corn each were taken from trucks delivering corn to the mill. The samples were collected randomly therefore different maize varieties from different producers and locals were sampled. Sampling followed that laid out by Brazil ${ }^{(6)}$ that deals with number of subsamples per truck, sample mixing and division, and how analyses should be carried out. The trucks were then unloaded and the material passed through a pre-cleaning process when another sample was taken, therefore, post cleaning samples were from the same trucks as pre-cleaning samples. The pre-cleaning machine installed in the mill has a capacity of 45 ton/hour and is equipped with $3 \mathrm{~mm}$ and $5 \mathrm{~mm}$ sieves with oblong holes.

Grading was adapted from Brazil ${ }^{(4)}$. Density (bushel weight) and relative humidity was analyzed using a Gehaka G800. Grains were classified according to their physical properties: percentages of foreign material, impurities, fragments, broken, soft, insect damaged, fire-burnt, fermented, damaged, cracked and fine particles, and was dependent of the sampling performed and the quality of corn that arrived before the pre-cleaning. 
The samples were stored in plastic bags and sent for chemical composition analysis in the laboratory of Adisseo do Brasil, including: apparent metabolizable energy for poultry (AME), ether extract (EE), crude fiber (CF), starch (STA), water activity (WA), crude protein (CP), digestible and total lysine, methionine, cystine, threonine, tryptophan, valine, isoleucine, leucine, phenylalanine, histidine and arginine. Total aminoacids were quantified by HPLC (High Performance Liquid Chromatography) and the other analysis by NIRS (Near InfraRed Spectrometry).

The calibration database for NIRS were obtained in more than 10 years of research experiments by Adisseo do Brasil including: chemical analysis, total amino acids (measured by HPLC), digestibility in-vivo of amino acids and apparent metabolizable energy (measured with cecectomy of cocks).

The experiment was a fully randomized design with two treatments (before and after pre-cleaning) and twenty replications. Data was analyzed using SAS ${ }^{\circledR}$ and treatment differences obtained using F test. Correlations between the physical and chemical traits were calculated and principal component analyses carried out to evaluate relationships between the traits.

\section{Results and Discussion}

The importance of pre-cleaning on the chemical and energetic characteristics of corn grain depends of the raw material quality that arrives at the feed mill, therefore, the control of physical quality of incoming grain to the feed mill is of utmost importance. Physical composition of corn before and after pre-cleaning is shown in Table 1. The corn grain before pre-cleaning was classified as Type 1 according to Brazil ${ }^{(4)}$ taking into consideration percentages of fire-burnt, impurities and fragments, and due to this, the two treatments had very similar results, since the corn evaluated had an excellent quality. Density was high compared to other studies ${ }^{(7,8)}$ but much lower than those found by Moore et al. ${ }^{(9)}$, Matin et al. ${ }^{(10)}$, and Ngonyamo-Majee et al. ${ }^{(11)}$ in the USA and Europe. This may be due to cultivar and growing condition differences between regions and countries, as well as drying and storage methods, but also reiterates the need for nutritionists to analyze the feedstuff before formulating rations. Different maize lineages are adapted to local growing conditions (soil type, temperature, altitude, and biotic and abiotic stresses) and desired human uses ${ }^{(12)}$, with different genotypes showing significantly different chemical compositions ${ }^{(13)}$.

Matin et al. ${ }^{(10)}$ found that there were significant differences in corn kernel dimensions before and after drying process, as well as between samples exposed to different drying temperature levels. Here, no control was taken over these parameters but there was a $30 \%$ difference in density levels in the samples studied (755.85 vs $1107 \mathrm{~g} / \mathrm{l})$.

Kernel density is affected by the relative proportions of the major nutrient components (e.g. starch and its ratio of amylose to amylopectin, protein and oil) and their packing within the kernel ${ }^{(14)}$. Density levels here are in line with those found by Duarte et al. ${ }^{(15,16,17)}$ in various corn hybrids grown in Brazil as well as Moore et al. ${ }^{(18,19)}$ in the USA. Matin et al. ${ }^{(10)}$ showed that in dry seasons density increased while in rainy seasons it decreased.

There was a decrease in density $(\mathrm{P}=0.090)$ after the pre-cleaning process which was due to the removal of earth and stones rather than grain and its fractions. Significant increases were found for insect damage, fermented and damaged grain while fire-burnt was significantly reduced. The lower weight fractions such as damaged and fermented were maintained in the corn samples and their proportion increased in the overall sample. Since their presence may affect chemical quality and energy content a new evaluation should be carried out after pre-cleaning as these fractions remain in the corn, in agreement with Fessel et al. ${ }^{(20)}$. Dale and Jackson ${ }^{(21)}$ showed that these fractions had less 
metabolized energy than whole grain. Pre-cleaning is important but does not solve grain quality problems.

Table 1: Physical composition of corn before and after pre-cleaning

\begin{tabular}{lccccc}
\hline \multirow{2}{*}{ Trait } & \multicolumn{2}{c}{ Before Pre-cleaning } & \multicolumn{2}{c}{ After Pre-cleaning } & $\mathrm{p}$ \\
& Mean & SD & Mean & SD & \\
\hline Density (grams per litre) & 755.85 & 21.86 & 742.20 & 27.49 & 0.090 \\
Foreign Material (Fm) \% & 0.018 & 0.055 & 0.009 & 0.040 & 0.580 \\
Impurities (Imp)\% & 0.215 & 0.152 & 0.164 & 0.105 & 0.266 \\
Fragments (Frag) \% & 0.693 & 0.489 & 0.848 & 0.528 & 0.342 \\
Fm+Imp+Frag \% & 0.925 & 0.494 & 1.021 & 0.515 & 0.553 \\
Broken \% & 3.900 & 1.624 & 4.334 & 1.372 & 0.367 \\
Soft \% & 0.161 & 0.167 & 0.253 & 0.216 & 0.138 \\
Insect damaged \% & 0.378 & 0.354 & 0.729 & 0.551 & 0.022 \\
Fire-burnt \% & 2.239 & 1.062 & 1.371 & 0.527 & 0.002 \\
Fermented \% & 0.898 & 0.614 & 1.387 & 0.660 & 0.020 \\
Damaged \% & 1.096 & 0.645 & 1.623 & 0.785 & 0.026 \\
Cracked \% & 8.681 & 2.821 & 9.776 & 2.261 & 0.183 \\
Fine particles \% & 0.202 & 0.465 & 0.026 & 0.018 & 0.100 \\
\hline SD-
\end{tabular}

SD- standard deviation, $\mathrm{P}$ - significance level

Impurity levels found here were lower than that found by Piedade et al. ${ }^{(22)}$ in corn samples from a feed mill in São Paulo State, Brazil, who observed that the contamination levels of non-sound kernels were higher than in sound kernels. Injured and broken kernels are more susceptible to fungal attack than whole kernels. Rambo et al. ${ }^{(23)}$ and Shotwell et al. ${ }^{(24)}$ observed a higher incidence of Aspergillus flavus in injured kernels while Shotwell et al. ${ }^{(25)}$ verified that corn fractions that presented insect damage, discoloration, injured and broken were more contaminated with aflatoxins. Pre-cleaning of the grain does little to improve sorter performance in terms of aflatoxin reductions ${ }^{(26)}$. Humidity was low which may increase corn kernel breakages ${ }^{(20)}$ and Alves et al. ${ }^{(27)}$ showed that the lower breaking rate was obtained when harvesting humidity was $15 \%$.

Chemical composition of the corn samples was shown in Table 2 and amino acids were in Table 3. Pre-cleaning is important to control problems with substances that reduce nutritional quality or add non-nutritional components to the corn in ration formulation. These non-nutritional components, especially leaves and earth, can increase humidity and allow fungus or other microorganisms to grow in rations, and in this experiment, pre-cleaning was effective in reducing humidity. Crude protein, ether extract levels and humidity were higher than those reported by Moore et al. ${ }^{(9,18,19)}$. Differences in humidity may explain density differences. These were also linked to water activity. Water activity levels were lower than those found in other studies ${ }^{(28)}$ where higher water activity led to higher fungal growth.

Crude protein levels observed for Jaeger et al. ${ }^{(3)}$ and Jiang et al. ${ }^{(29)}$ were higher than the values observed in the present study, while starch levels were similar to those found by Ngonyamo-Majee et al. ${ }^{(11)}$.

As expected, starch increased after pre-cleaning which is a result of the removal of contaminants which normally are poor in this carbohydrate, but fiber levels increased too, although it was expected that fiber components, especially straw and pieces of corn cobs should be separated in precleaning process. Apparent metabolizable energy levels was not affected by pre-cleaning $(\mathrm{P}=$ 0.093). According to Baidoo et al. ${ }^{(30)}$ the amount of metabolizable energy is directly correlated to density of the grain mass and, by the way, is directly dependent to fiber levels. Dale and Jackson ${ }^{(21)}$ inform that high variation can be found in metabolizable energy in corn grains and the 
different fractions that occur in different amounts affect metabolizable energy and protein, fat, fiber and mineral content. Fiber levels observed in the present study are lower than observed by Moore et al. ${ }^{(19)}$ who showed that high fiber may prevent poultry from completely digesting starch, reducing growth and feed efficiency.

Table 2: Chemical composition of Corn in a Brazilian Feed Mill before and after pre-cleaning

\begin{tabular}{lccccc}
\hline \multirow{2}{*}{ Variable } & \multicolumn{4}{c}{ Before Pre- } & \multicolumn{3}{c}{ After Pre- } \\
& Cleaning & \multicolumn{2}{c}{ cleaning } \\
& Mean & SD & Mean & SD & P \\
\hline Humidity (\%) & 11.670 & 0.323 & 11.139 & 0.311 & 0.0001 \\
Apparent Metabolizable Energy for Poultry $(\mathrm{kcal} / \mathrm{kg})$ & 3941 & 24.54 & 3927 & 28.15 & 0.093 \\
Ether Extract (\%) & 4.149 & 0.129 & 4.115 & 0.049 & 0.287 \\
Crude Fiber (\%) & 1.860 & 0.159 & 2.074 & 0.089 & 0.0001 \\
Starch (\%) & 67.512 & 2.798 & 70.976 & 2.524 & 0.0001 \\
Water Activity ( $\left.\mathrm{a}_{\mathrm{w}}\right)$ & 0.522 & 0.033 & 0.472 & 0.034 & 0.0001 \\
Crude Protein (\%) & 7.205 & 0.399 & 7.090 & 0.252 & 0.288 \\
\hline SD-
\end{tabular}

SD- standard deviation, $\mathrm{P}$ - significance level

Table 3: Amino Acid composition of corn before and after pre-cleaning

\begin{tabular}{lccccc}
\hline \multirow{2}{*}{ Variable } & \multicolumn{2}{c}{ Before Pre-Cleaning } & \multicolumn{4}{l}{ After Pre-cleaning } \\
& Mean & SD & Mean & SD & P \\
\hline Digestible Lysine & 0.183 & 0.009 & 0.181 & 0.006 & 0.337 \\
Digestible Methionine & 0.153 & 0.011 & 0.150 & 0.004 & 0.225 \\
Digestible Cystine & 0.151 & 0.010 & 0.151 & 0.007 & 0.856 \\
Digestible Threonine & 0.230 & 0.021 & 0.226 & 0.008 & 0.442 \\
Digestible Tryptophan & 0.050 & 0.002 & 0.050 & 0.002 & 1.000 \\
Digestible Valine & 0.333 & 0.030 & 0.327 & 0.012 & 0.457 \\
Digestible Isoleucine & 0.257 & 0.024 & 0.252 & 0.009 & 0.343 \\
Digestible Leucine & 0.983 & 0.098 & 0.953 & 0.036 & 0.192 \\
Digestible phenylalanine & 0.350 & 0.037 & 0.340 & 0.015 & 0.281 \\
Digestible Histidine & 0.203 & 0.019 & 0.192 & 0.007 & 0.016 \\
Digestible Arginine & 0.328 & 0.022 & 0.322 & 0.007 & 0.293 \\
Total Lysine & 0.208 & 0.011 & 0.202 & 0.006 & 0.070 \\
Total Methionine & 0.162 & 0.012 & 0.157 & 0.004 & 0.065 \\
Total Cystine & 0.186 & 0.011 & 0.188 & 0.08 & 0.508 \\
Total Threonine & 0.270 & 0.023 & 0.267 & 0.007 & 0.521 \\
Total Tryptophan & 0.059 & 0.004 & 0.060 & 0.002 & 0.657 \\
Total Valine & 0.378 & 0.036 & 0.371 & 0.013 & 0.417 \\
Total Isoleucine & 0.274 & 0.026 & 0.266 & 0.010 & 0.239 \\
Total Leucine & 0.994 & 0.096 & 0.965 & 0.035 & 0.227 \\
Total phenylalanine & 0.368 & 0.041 & 0.354 & 0.016 & 0.195 \\
Total Histidine & 0.220 & 0.020 & 0.208 & 0.007 & 0.012 \\
Total Arginine & 0.355 & 0.021 & 0.351 & 0.007 & 0.383 \\
\hline SD standan & & & & &
\end{tabular}

SD- standard deviation, $\mathrm{P}$ - significance level

As crude protein levels did not change with the pre-cleaning process, changes in amino acids (AA) 
were not expected and this was the case for most AA studied in this study. Nevertheless, digestible $(\mathrm{P}=0.016)$ and total $(\mathrm{P}=0.012)$ histidine reduced its levels after pre-cleaning. Lilburn and Dale ${ }^{(31)}$ observed that methionine, lysine and total sulfur amino acids increased linearly as the bushel weight increased, which are not confirmed in this study. Cystine, histidine, metionine, phenylalanine and threonine levels were in general higher than reported by Moore et al. ${ }^{(9)}$, while leucine and tryptophan were lower and the others approximately the same. Moore et al. ${ }^{(19)}$ showed that lysine and metionine contents of the kernels contributed each with $8 \%$ to the variation in feed consumption, and lysine and metionine contributed with 17 and $11 \%$, respectively, to the variation in feed utilization of starter phase broilers.

Table 4: Correlations between physical properties of corn in a feed mill

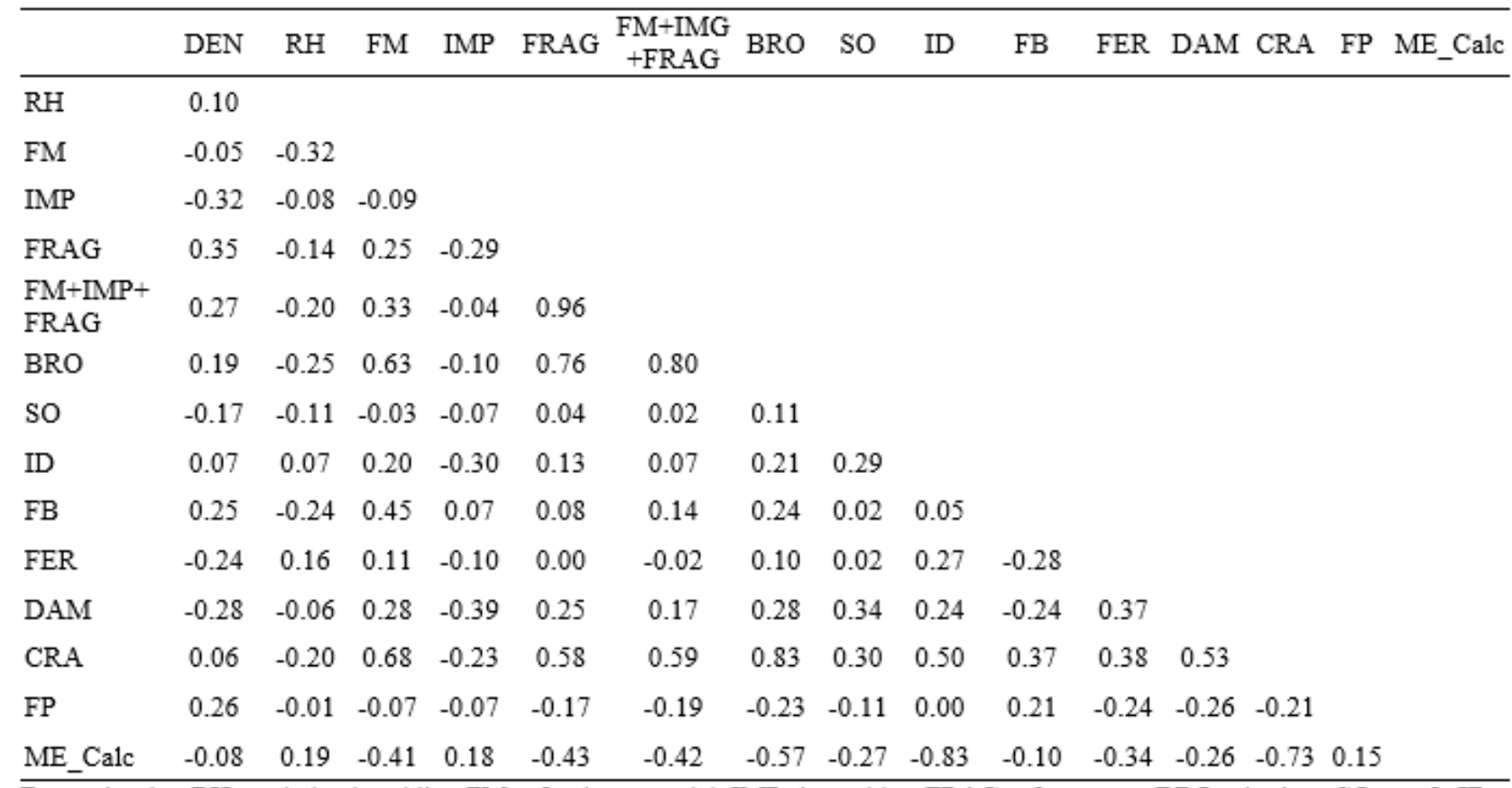

Den - density, RH - relative humidity, FM - foreign material, IMP- impurities, FRAG - fragments, BRO - broken, SO - soft, ID insect damaged, FB - fire-burnt, FER - fermented, DAM - damaged, CRA - cracked, FP - fine particles, ME_calc - calculated metabolizable energy

Correlations between physical properties of corn are shown in Table 4. Significant correlations $(\mathrm{P}<0.05)$ were found between density and \% impurities $(-0.31)$ and fragments $(0.35)$. Density was higher when there were fewer impurities such as straw, husk or small grains which pass through a 5 $\mathrm{mm}$ sieve. When the corn was more fragmented density was higher as it occupies less space and there is less air in the sample. Broken corn was positively correlated $(\mathrm{P}<0.05)$ with foreign material $(0.63)$ and fragments $(0.76)$, while proportion of damaged corn was positively correlated with foreign material (0.68), fragments (0.58) and broken corn (0.83). This indicates that lack of care in harvesting, drying, transport and storage may increase all types of physical damage to the grain and their correlated relationships with grain quality as discussed above. In general, all other correlations between traits analyzed were not significant $(\mathrm{P}>0.05)$. According to Carvalho and Nakagawa ${ }^{(27)}$ the incidence of broken corn starts to increase as water content goes below $12-14 \%$, while from $16-18 \%$ the grain suffers from squashing, therefore the ideal would be between these measures, however in this study there was no correlation of relative humidity with any physical characteristics of the grains.

The principal component analysis showed that $54 \%$ of all variation of traits was described by the first two autovectors (Figure 1). As described by the first principal component, higher calculated 
metabolizable energy was accompanied by less impurties in the sample. In the second component higher density was accompanied by more broken and fragmented grains with more fine particles. These leave less room in the sample for air, thereby increasing density. This higher density was also accompanied by less soft, insect damaged, damaged and fermented grains. These grains have less endosperm thereby becoming lighter.

The principal component analysis of amino acids and chemical analysis (Figure 2) shows that with an increase in protein levels there is an increase in valine, histidine, arginine, leucine, metionine, histidine, lysine, isoleucine while apparent metabolizable energy and damaged was lower. The second component shows a subgroup with high damage and crude fiber content with low apparent metabolizable energy, water activity and relative humidity. These results are in agreement with Rodrigues et al. ${ }^{(2)}$. Fiber directly affects energy content of the grain, as the bird does not use this component to produce energy. Grains with more fiber have a lower relative humidity and consequently lower water activity.

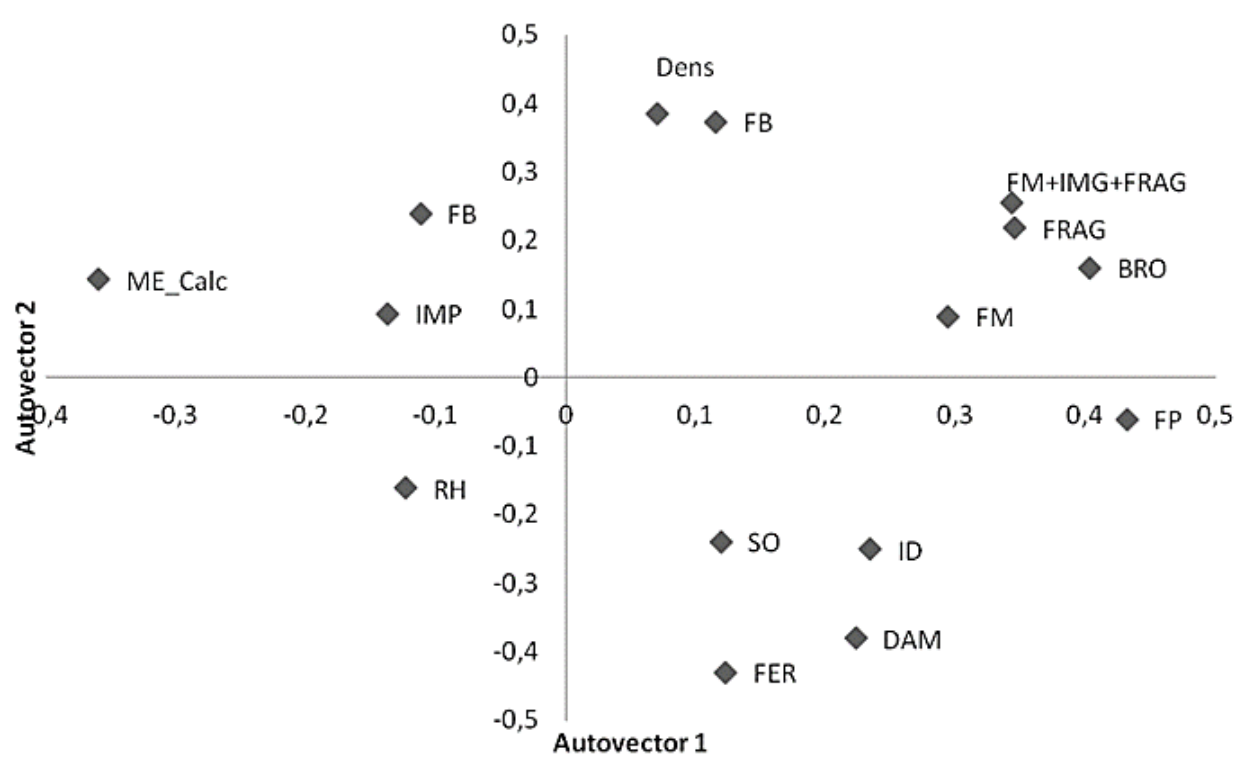

Figure 1: Principal components for physical properties of corn.

Den - density, RH - relative humidity, FM - foreign material, IMP- impurities, FRAG - fragments, BRO - broken, SO - soft, ID - insect damaged, FB - fire-burnt, FER - fermented, DAM - damaged, CRA - cracked, FP - fine particles, ME_calc - calculated metabolizable energy 


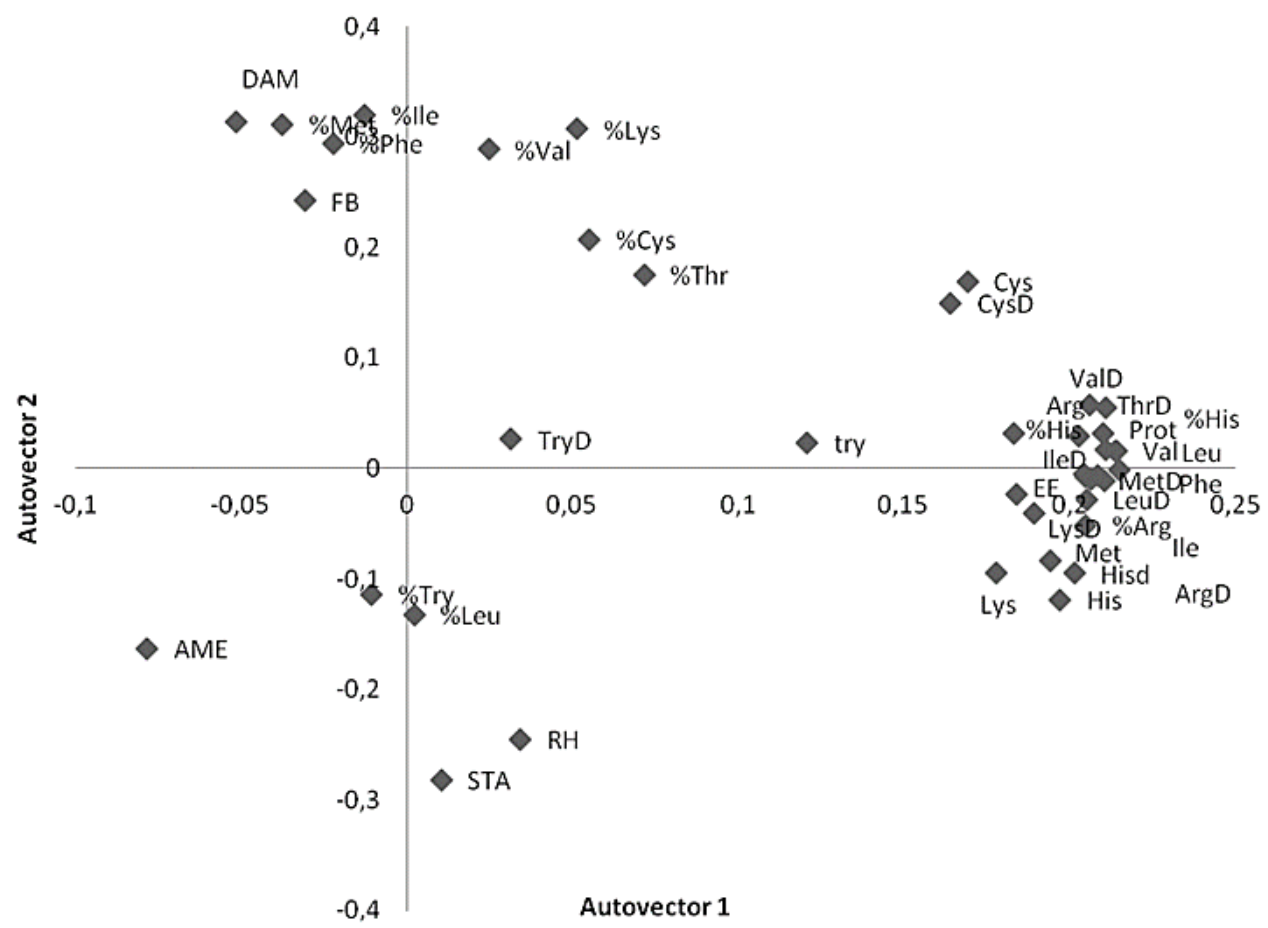

Figure 2: Principal components for amino acids and chemical properties of corn

\section{Conclusion}

In this study, even though the samples were classified as excellent quality before the pre-cleaning, the pre-cleaning process was effective to reduce humidity and water activity that helps control the growth of fungus or other microorganisms in rations.

Starch and fiber levels increased after pre-cleaning while apparent metabolizable energy levels was not improved by pre-cleaning.

Pre-cleaning is important but does not solve grain quality problems.

\section{References}

1. Donohue M, Cunnigham DL. Effects of grain and oilseed prices of costs of US poultry production. J Appl Poult Res. 2009; 18(2): 325-337.

2. Rodrigues SIFC, Stringhini JH, Ribeiro AML, Pontalti GC, McManus CM. Quality assessment of corn batches received at a feed mill in the Brazilian cerrado. Rev Bras Cienc Avic. 2014, 16(3): 233-240.

3. Jaeger SL, Luebbe MK, Macken CN, Erickson GE, Klopfenstein TJ, Fithian WA, Jackson DS. Influence of corn hybrid traits on digestibility and the efficiency of gain in feedlot cattle. J Anim Sci. 2006; 84(7):1790-1800.

4. Brasil. Ministério da Agricultura, Pecuária e Abastecimento. Portaria n. 845 de 8 de novembro de 1976. 
Available

from:

http://sistemasweb.agricultura.gov.br/sislegis/action/detalhaAto.do?method=consultarLegislacaoFederal.

Portuguese.

5. Stringhini JH; Mogyca NS, Andrade MA; Orsine GF; Café MB; Borges SA. Efeito da qualidade do milho no desempenho de frangos de corte. R. Bras. Zootec. [online]. 2000, vol.29, n.1, pp. 191-198. Portuguese. Available from http://www.scielo.br/pdf/rbz/v29n1/5749.pdf

6. Brasil. Ministério da Agricultura, Pecuária e Abastecimento. Portaria n. 108 de 4 de setembro de 1991. Available from: http://sistemasweb.agricultura.gov.br/sislegis/action/detalhaAto.do?method=consultarLegislacaoFederal.

Portuguese.

7. Leeson S, Yersin A, Volker L. Nutritive value of the 1992 corn crop. J Appl Poul Res. 2(3): 208-213.

8. Paulsen MR, Hofing SL, Hill LD, Eckhoff SR. Corn Quality Characteristics for Japan Markets. Appl Eng Agric. 1996; 12(6):731-738.

9. Moore SM, Bregendahl K, Stalder KJ, Beitz DC, Stahl CH, Fithian WA. Corn Hybrid Kernel Trait Variation Affects Laying-Hen Egg Production. 2006 Iowa State University and USDA Poultry Science Day Report. 5p. Available from: http://www.ans.iastate.edu/research/psd/ASL22141.pdf

10. Matin A, Krička T, Voća N, Jukić Ž, Janušić V. Impact of Drying on Dimensions of Corn Kernel Grown at Different Agrotechnological Levels. Agric Conspec Sci. 2007; 72(3):205-209.

11. Ngonyamo-Majee D, Shaver RD, Coors JG, Sapienza D, Correa CES, Lauer JG, Berzaghi P. Relationships between kernel vitreousness and dry matter degradability for diverse corn germplasm. I. Development of near-infrared reflectance spectroscopy calibrations. Anim Feed Sci Tech. 2008; 142(34):247-258.

12. Flint-Garcia SA, Bodnar AL, Scott MP. Wide variability in kernel composition, seed characteristics, and zein profiles among diverse maize inbreds, landraces, and teosinte. Theor Appl Genet. 2009; 119(6):11291142.

13. Osorno JM, Carena MJ. Creating groups of maize genetic diversity for grain quality: implications for breeding. Maydica. 2008; 53(2): 131-141.

14. Paulsen MR, Watson SA, Singh M. Measurement and maintenance of corn quality. In: White PJ, Johnson LA. Corn: Chemistry and Technology. 2nd ed. St. Paul: AACC; 2003. p. 159-220.

15. Duarte AP, Mason SC, Jackson DS, KiehL JC. Grain Quality of Brazilian Maize Genotype as Influenced by Nitrogen Level. Crop Sci. 2005; 45(5): 1958-1864.

16. Duarte AP, Rodrigues DH, Côrrea PC, Paterniani MEAGZ. Produtividade, aparência, densidade e suscetibilidade à quebra dos grãos em híbridos de milho safrinha. Rev Bras Milho Sorgo. 2007; 6(2): 174185.

17. Duarte AP, Carvalho CRL, Cavichioli JC. Densidade, teor de óleo e produtividade de grãos em híbridos de milho. Bragantia. 2008; 67(3):759-767.

18. Moore SM, Stalder KJ, Beitz DC, Stahl CH, Fithian WA, Bregendahl K. The correlation of chemical and physical corn kernel traits with growth performance and carcass characteristics in pigs. J. Anim Sci. 2008; 86(3):592-601.

19. Moore SM, Stalder KJ, Beitz DC, Stahl CH, Fithian WA, Bregendahl K. The correlation of chemical and physical corn kernel traits with production performance in broiler chickens and laying hens. Poultry Sci. 2008; 87(4):665-676.

Cienc. anim. bras. v.16, n.2, p. 158-168 abr./jun. 2015 
20. Fessel AS, Sader R, Paula RC, Galli JA. Quality evaluation of corn seeds during conditioning. Rev Bras sementes. 2003; 25(2): 70-76.

21. Dale N, Jackson D. True metabolizable energy of corn fractions. J Appl Poult Res. 1994; 3(2):179-183.

22. Piedade FS., Fonseca H, Gloria, EM, Calori-Domingues MA, Piedade SMS, Barbin D. Distribution of aflatoxins in corn fractions visually segregated for defects. Braz J Microbiol. 2002; 33(3): 250-254.

23. Rambo GD, Tuite J, Caldwell RW. Aspergillus flavus and aflatoxin in preharvest corn from Indiana in 1971 and 1972. Cereal Chem. 1974; 51:848-853.

24. Shotwell OL, Goulden ML, Hesseltine CW. Aflatoxin contamination: association with foreign material and characteristic fluorescence in damaged corn kernels. Cereal Chem. 1972; 49:458-465.

25. Shotwell OL, Goulden ML, Lillejoj EB, Kwolek WF, Hesseltine CW. Aflatoxin occurrence in 1973 corn at harvest. III. Aflatoxin distribution in contaminated, insect-damaged corn. Cereal Chem. 1975; 54:620626.

26. Pearson TC, Wicklow DT. Optical sorting: detecting whole corn kernels contaminated with aflatoxin or fumonisin. Resour Eng Technol Sustainable World. 2004. Available from: http://findarticles.com/p/articles/mi hb4979/is 8 11/ai n29126267

27. Alves;WM; Faroni LRD; Queiroz DM; Corrêa PC; Galvão JCC. Qualidade dos grãos de milho em função da umidade de colheita e da temperatura de secagem. Rev. Bras. Eng. Agric. Ambient. 2001, v.5, n.3, p. 469-474. Portuguese. Available from http://www.scielo.br/pdf/rbeaa/v5n3/v5n3a17.pdf

28. Samapundo S, Devlieghere F, Geeraerd AH, De Meulenaer B, Van Impe JF, Debevere J. Modelling of the individual and combined effects of water activity and temperature on the radial growth of Aspergillus flavus and A. parasiticus on corn. Food Microbiol. 2007; 24(5):517-529.

29. Jiang HY, Zhu YJ, Wei LM, Dai JR, Song TM, Yan YL,Chen SJ. Analysis of protein, starch and oil content of single intact kernels by near infrared reflectance spectroscopy (NIRS) in maize (Zea mays L.) Plant Breed. 2007; 126(5):492-497.

30. Baidoo SK, Shires A, Robblee AR. Effect of kernel density on apparent and true metabolizable energy value of corn for chickens. PoulSci. 1991; 70(10):2102-2107.

31. Lilburn MS, Dale N. Research Note: Characterization of two samples of corn that vary in bushel weight. Poultry Sci. 1989; 68(6):857-860. 